\title{
Effect of different fractions of Hibiscus rosa sinensis leaf extract on islets of Langerhans and antioxidant activity in non-obese diabetic (NOD) mouse
}

\author{
Fahmi S. M oqbel and Prakash R. Naik* \\ Endocrinology Laboratory, Department of Studies in Zoology, University of Mysore, Manasagangotri, Mysore-570 006 \\ (Karnataka), INDIA \\ "Correspondence author. E-mail: prakashrnaik@yahoo.co.in
}

\begin{abstract}
The present investigation was undertaken to study the effect of Hibiscus rosa sinensis leaf extract fractions on islets of Langerhans, total antioxidant activity in non-obese diabetic (NOD) mouse. Two sets of experiments were conducted. First experiment was designed to test the hypoglycemic properties of different isolated fractions. Five fractions were screened for hypoglycemic property. Fractions $F_{3}, F_{4}$ and $F_{5}$ showed hypoglycemic in NOD mice. Second set of experiment was conducted to assess the effects of above fractions on the diameter of islets of Langerhans and on the $\beta$-cells number and total antioxidant capacity (TAC). All the fractions had a significant effect in the enhancement of diameter of islets of Langerhans and the $\beta$-cell number and antioxidant active (total antioxidant capacity) compared with control NOD mice.
\end{abstract}

Keywords: Blood glucose, Islets of langerhans, Total antioxidant capacity, Non-obese diabetic mice

\section{INTRODUCTION}

Diabetes mellitus describes a heterogeneous group of metabolic disorders characterized clinically and metabolically by elevated blood glucose levels (hyperglycemia). These features result from the low effect of insulin, either because of insulin deficiency alone (type-1diabetes mellitus: type-1D), or because of defective insulin secretion in relation to a decrease in insulin sensitivity (type-2 diabetes mellitus) (Ganong, 1999).

Type-I diabetes or insulin-dependent diabetes mellitus (IDDM) is thought to be an autoimmune disease in humans (Castano and Eisenbarth, 1990; Rossini et al., 1989; Acha-Orbea and McDevitt, 1990). Nonobese diabetic (NOD) mice spontaneously develop diabetes, which has features similar to those of human type-1 diabetes, a polygenetic disease resulting from an inadequate amount of $\beta$-cells mass caused by T-cellmediated autoimmune destruction of $\beta$-cells (Makino et al., 1980; Cahill and McDevitt, 1981; Gorsuch et al., 1981). Hibiscus rosa sinensis L. (Malvaceae) is a popular herb in traditional system of medicine. Ethanomedical information states that the plant possesses powerful antioxidant (Masaki et al., 1995), antidiabetic (Sachdewa and Khemani, 2003) cardioprotective (Gauthaman et al., 2006), hepatoprotective (Obi and Uneh, 2003), and anticancer (Sharma et al., 2004) properties in various models.

The islets of Langerhans play a central role in the hormonal control of fuel metabolism and particularly of glucose homeostasis. Maintenance of a normal plasma glucose concentration during periods of food consumption and fasting requires a delicate balance between glucose production and utilization. Although control of glucose homeostatsis implicates many hormonal, neural, and autoregulatory factors, insulin and glucagon, two secretory products of the islets, are the major determinants of this control. Insulin is secreted by the $\beta$-cells of the islets in response to nutrients to promote energy storage in target organs (liver, muscle, and adipose tissue); glucagon release by the $\alpha$-cell is then inhibited in the postabsorptive state, while insulin secretion falls, glucagon is stimulated and activates glycogenolysis and gluconeogenesis; this reciprocal change in the plasma insulin-glucagon concentration ratio will favor energy store consumption. Biosynthesis and secretion of these two hormones must be tightly regulated to match fuel production and delivery to metabolic demands. (Philippe, 1991). Various studies have shown that diabetes mellitus is associated with increased formation of free radicals and decrease in antioxidant potential. Due to these events, the balance normally present in cells between radical formation and protection against them is disturbed. This leads to oxidative damage of cell components such as proteins, lipids, and nucleic acids. In both insulin dependent (type- 1) and noninsulin-dependent diabetes (type- 2) there is increased oxidative stress (Nazirogilu and Butterworth, 2005). Nutritional factors including antioxidants have great influence in the management of diabetes mellitus and its 
complications (Alberti et al., 1997; Packer et al., 2000). An imbalance between oxidative stress and antioxidative defense mechanisms in diabetics can result in cell and tissue damage and accelerate diabetic complications. Administration of appropriate antioxidants could prevent or retard diabetic complications to some extent (Packer et al., 2000). Recently, some evidences suggest that oxidative stress may play an important role in the etiology of diabetes and diabetic complications (Shinn, 1998). In healthy individuals, oxidative damage to tissue is prevented by a system of defenses which includes antioxidant enzymes and small molecules with scavenging ability such as antioxidant vitamins (Polidori et al., 2000) However, relationships between the antioxidant status, glycemic control, and the risk for development of chronic complication in individuals with diabetes are not completely clear (Abuaisha et al., 1998). Antioxidants play an important role to protect against damage by reactive oxygen species and their role in diabetes has been evaluated. Many plant extract and products were shown to possess significant antioxidant activity. The present investigation was undertaken to study the effect of Hibiscus rosa sinensis leaf extract fractions on islets of Langerhans, total antioxidant activity in non-obese diabetic (NOD) mouse.

\section{MATERIALS AND METHODS}

A nimals models: NOD mice were originally obtained from Center for Cellular and Molecular Biology (CCMB, CSIR), Hyderabad and maintained under standard environmental conditions of 12:12 h L: D cycle. Mice were fed with standard diet supplied by Ambruth Feeds Pvt Ltd Bangalore and water ad libitum. Healthy adult of (30 weeks old) NOD mice of either sex weighing 25-30 g were selected for the study from the Central Animal Facility of the department. All the selected animals showed the fasting blood glucose values of e" $242 \mathrm{mg} / 100 \mathrm{ml}$ indicting hyperglycemia, the diabetic status. Experimental protocols were approved from Institutional Animal Ethics Committee (IAEC).

Extraction and fractionation: Healthy disease free leaves of $\mathrm{H}$. rosa sinensis were collected from the garden of our University campus. The authenticity of the plant was confirmed by a taxonomist of the Department of Botany. University of Mysore, Mysore, and preserved in the form of herbarium. Collected leaves were shade dried and ground in warring blender. The ground powder was extracted in soxhlet apparatus using ethanol until the final drop of the extract became color less. The extract was dried using evaporator.Details of extraction and fractionation of $\mathrm{H}$. rosa sinensis is published elsewhere (Moqbel et al., 2011). After fractionation the five fractions were obtained namely ethyl acetate soluble fraction $\left(F_{1}\right)$, ethyl acetate insoluble fraction $\left(\mathrm{F}_{2}\right)$, chloroform fraction
$\left(\mathrm{F}_{3}\right)$, the basic fraction $\left(\mathrm{F}_{4}\right)$ and neutral fraction $\left(\mathrm{F}_{5}\right)$. First experiment was conducted to test the hypoglycemic properties of the five fractions obtained. Since $\mathrm{F}_{2}$ did not dissolve in tween-80, $1 \%$, remaining fractions $\mathrm{F}_{1}, \mathrm{~F}_{3}, \mathrm{~F}_{4}$ and $\mathrm{F}_{5}$ were dissolved in tween-80 (1\%) with two concentrations of 100 and $200 \mathrm{mg} / \mathrm{kg}$ body weight and fed orally to NOD mice. The animals with body weight ranging between 25-30 g they were allowed with free access to standard laboratory food and water ad libitum throughout the experiment. NOD mice were randomly divided in to the following groups with five animals in each.

Group I: NOD diabetic control treated with vehicle alone. Group II: NOD mice treated with insulin (1 ml of Biphasic isophane insulin purchased from pharmaceutical company dissolved in $100 \mathrm{ml}$ saline and $0.1 \mathrm{ml} /$ mouse / day was injected (intra peritoneal). Group III: NOD mice treated with $100 \mathrm{mg} / \mathrm{kg}$ body weight of $\mathrm{F}$. Group IV: NOD mice treated with $200 \mathrm{mg} / \mathrm{kg}$ body weight of $\mathrm{F}_{1}$. Group $\mathrm{V}$ : NOD mice treated with $100 \mathrm{mg} / \mathrm{kg}$ body weight of $F_{3}$. Group VI: NOD mice treated with $200 \mathrm{mg} / \mathrm{kg}$ body weight of $\mathrm{F}_{3}$. Group VII: NOD mice treated with $100 \mathrm{mg} / \mathrm{kg}$ body weight of $\mathrm{F}_{4}$.Group VIII: NOD mice treated with $200 \mathrm{mg} /$ $\mathrm{kg}$ body weight of $\mathrm{F}_{4}$. Group IX: NOD mice treated with $100 \mathrm{mg} / \mathrm{kg}$ body weight of $\mathrm{F}_{5}$. Group X: NOD mice treated with $200 \mathrm{mg} / \mathrm{kg}$ body weight of $F_{5}$.

Since $F_{1}$ did not show hypoglycemia whereas fractions $\mathrm{F}_{3}, \mathrm{~F}_{4}$ and $\mathrm{F}_{5}$ showed hypoglycemia. Hence second experiment was conducted choosing $\mathrm{F}_{3}, \mathrm{~F}_{4}$ and $\mathrm{F}_{5}$ fractions for detailed investigation to study antioxidant activity and the effect on the Islets of Langerhans.

Experimental protocols: NOD mice were randomly divided into following 8 groups of 5 animals in each group: Group- I: NOD diabetic control treated with vehicle alone, Group- II: NOD mice treated with insulin (1 ml of Biphasic isophane insulin purchased from pharmaceutical company dissolved in $100 \mathrm{ml}$ saline and $0.1 \mathrm{ml} /$ mouse / day was injected intraperitoneally).

Group- III: NOD mice treated with $100 \mathrm{mg} / \mathrm{kg} \mathrm{b} . \mathrm{w}$ of $\mathrm{F}_{3}$ Group- IV: NOD mice treated with $200 \mathrm{mg} / \mathrm{Kg}$ b.w of $\mathrm{F}_{3}$ Group- V: NOD mice treated with $100 \mathrm{mg} / \mathrm{kg}$ b.w of $\mathrm{F}_{4}$ Group- VI: NOD mice treated with $200 \mathrm{mg} / \mathrm{Kg}$ b.w of $\mathrm{F}_{4}$ Group- VII: NOD mice treated with $100 \mathrm{mg} / \mathrm{kg}$ b.w of $\mathrm{F}_{5}$ Group- VIII: NOD mice treated with $200 \mathrm{mg} / \mathrm{Kg}$ b.w of $\mathrm{F}_{5}$ $\mathrm{F}_{3}, \mathrm{~F}_{4}$ and $\mathrm{F}_{5}$ were dissolved in tween- $80(1 \%)$ and Fed orally to the animals of group- III - VIII. The experiment was conducted for four weeks.

In the above experiment, body weight was recorded at the commencemen of the experiment ( 0 day) and weekly to the day of autopsy. Final body weight and pancreas weight was also recorded and later pancreas weight was converted into relative weight (weight (mg) / $100 \mathrm{~g} \mathrm{b.w).}$ Overnight fasted animals were used in all the experiments. During the tenure of the experiment, blood was drawn 
from tail of conscious mice once in a week in every group to estimate glucose level by glucometer.

M or phometric analysis: All the groups had 5 NOD mice each in it. From single mice 100 islets were measured from 100 randomly selected cross sections of the pancreas from each mice and also their $\beta$-cells were counted, totally 500 islets were considered for the morphometric analyses from each group. Islets of Langerhans measurement was done at their longest axis at $400 \mathrm{X}$ and size was calculated and it was done using ocular microscope fixed in Correct Seiwa Optical (No. 621734) light microscope (diameter-at horizontal and vertical axis of every islet was measured and divided by 2). The total number of $\beta$-cells of the islets was done by point counting using blood cell counter (Chandavar and Naik, 2004).

CHP stained histological sections slides were photographed using Olympus B $\times 60$ Microscope.

Total antioxidant capacity was estimated based on the method of Berker et al., (2009). Briefly $0.1 \mathrm{ml}$ of sample, $0.9 \mathrm{ml}$ of $\mathrm{EtOH}(96 \%), 5 \mathrm{ml} \mathrm{H} \mathrm{O}, 1.5 \mathrm{ml}$ of $1 \mathrm{M} \mathrm{HCl}, 1.5 \mathrm{ml}$ of ferricyanide solution (1\%), $0.5 \mathrm{ml}$ of $1 \%$ sodium dodecyl sulfate (SDS), and 0.5 of $\mathrm{FeCl}_{3} \cdot 6 \mathrm{H}_{2} \mathrm{O}(0.2 \%)$ were added and the volume was made up to $10 \mathrm{ml}$. the mixture was incubated at $50^{\circ} \mathrm{Con}$ a water bath for $20 \mathrm{~min}$ cooled and optical density $(\mathrm{OD})$ was absorbed at $750 \mathrm{~nm}\left(\mathrm{~A}_{750}\right)$. The total antioxidant activity was calculated by using the formula: $\mathrm{TAC}(\mathrm{mmol} \mathrm{TR} / \mathrm{g})=(\mathrm{Af} / \varepsilon \mathrm{TR}) \times(\mathrm{Vf} / \mathrm{Vs}) \times \mathrm{r}(\mathrm{Vcup} /$ $\mathrm{m})$.

Statistical analysis: The mean value of each parameter was computed considering data on five NOD mice in each group. The mean values of each parameter of different groups were compared using one-way analysis of variance (ANOVA) followed Duncan's new multiple range test fixing a minimum significance level of $\mathrm{p}<0.05$.

\section{RESULTS}

Table 1 shows the result of first experiment on effect of different fractions obtained on the serum glucose level of all the groups. Group-I animals (NOD diabetic control) exhibited hyperglycemia throughout the experiment indicating diabetic status where as group-II animals after treatment with insulin significantly reduced the serum glucose level to non diabetic status. Group-III animals ( $F_{1}$ with $100 \mathrm{mg} / \mathrm{kg}$ body weight) continued to maintain diabetic status where as group IV animals $\left(\mathrm{F}_{1}\right.$ with 200 $\mathrm{mg} / \mathrm{kg}$ body weight) showed significant reduction in serum glucose level but failed to attain non diabetic status. Animals treated with $\mathrm{F}_{3}$ and $\mathrm{F}_{5}$ with different concentrations (group-V and group-VI, Group-IX and group-X) exhibited the serum glucose level even lesser than insulin treated group (group-II). Animals of groupVII and-VIII treated with fraction $\mathrm{F}_{4}$ showed a significant reduction of serum glucose level compared to NOD diabetic control; however $\mathrm{F}_{4}$ with $200 \mathrm{mg} / \mathrm{kg}$ body weight performed better.

Table 2 shows the mean values of weight of pancreas, relative weight of pancreas, islet diameter and $\beta$-cells number per islet. Absolute weight and relative weight of pancreas did not differ significantly in all the experimental groups, however there were significant enhancement in the diameter of the islets in the experimental groups compared to NOD mice (group-I). $\beta$-cells number were maximum in the islets after oral feeding of $\mathrm{F}_{3}$ with $100 \mathrm{mg} /$ $\mathrm{kg}$ body weight (group-III). There was a significant enhancement in the number of $\beta$ cells in all the remaining groups compared to NOD mice (group-I).

Fig. 1 shows total antioxidant capacity (TAC) in different groups of experimental animals. TAC value was found to be $0.029 \pm 0.0004 \mathrm{mmol} / \mathrm{g}$ in NOD mice, where as the value ranged from $0.041 \pm 0.0004$ to $0.061 \pm 0.0005$ in different experimental groups with fractions $\mathrm{F}_{3}, \mathrm{~F}_{4}, \mathrm{~F}_{5}$ and insulin. TAC of group $\mathrm{V}$ reached almost with that of insulin treated group.

\section{DISCUSSION}

It is evident from Table- 1 that fraction $\mathrm{F}_{1}$ had no effect in lowering the blood serum glucose level in NOD mice where as the fraction $\mathrm{F}_{3}, \mathrm{~F}_{4}, \mathrm{~F}_{5}$ had reduced the serum glucose level significantly to non diabetic status. Comparatively fraction $\mathrm{F}_{3}$ performed better in lowering blood serum glucose level than fractions $\mathrm{F}_{4}$ and $\mathrm{F}_{5}$. The fraction $\mathrm{F}_{5}$ performed better than fraction- 4 . Fraction- 4 with $200 \mathrm{mg} / \mathrm{kg}$ body weight reduced the blood serum

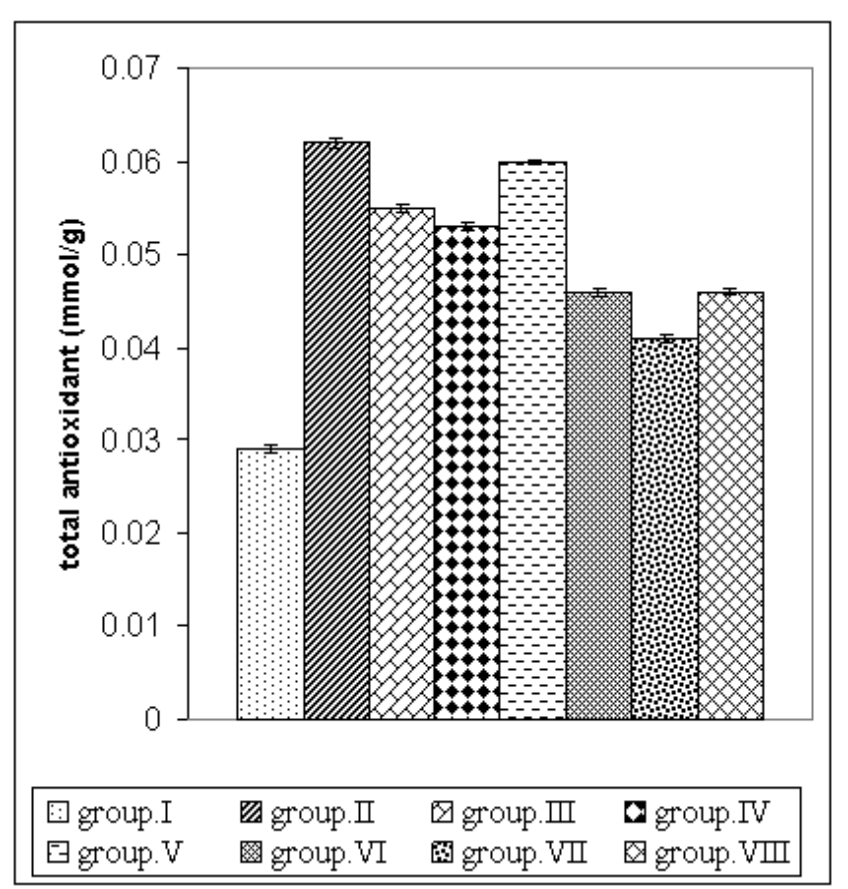

Fig. 1. Effect of of leaf extract of $H$. rosa sinensis (HLE) fractions $\left(F_{3}, F_{4}, F_{5}\right)$ on Total antioxidant (mmol/g) of experimental groups.

The vertical bars are showing mean values of total antioxidant $(\mathrm{mmol} / \mathrm{g})$. Lines above the bars indicate standard error (SE). 
Table 1. Effect of leaf extract of $\mathrm{H}$. rosa sinensis (HLE) all fractions $\left(\mathrm{F}_{1}, \mathrm{~F}_{3}, \mathrm{~F}_{4}, \mathrm{~F}_{5}\right)$ on serum glucose level (mg/dl).

\begin{tabular}{|c|c|c|c|c|c|}
\hline Group & 0 day & $7^{\mathrm{cn}}$ day & $14^{\text {nn }}$ day & $21^{\text {st }}$ day & $28^{\text {tn }}$ day \\
\hline I. NOD mice control & $287 \pm 2.77^{\mathrm{a}}$ & $279.8 \pm 2.82^{\mathrm{a}}$ & $280 \pm 3.65^{\mathrm{a}}$ & $283 \pm 3.66^{\mathrm{a}}$ & $281.6 \pm 3.79^{\mathrm{a}}$ \\
\hline II. Insulin injected NOD mice & $242.4 \pm 1.38^{\mathrm{b}}$ & $202.95 \pm 4.09^{\mathrm{b}, \mathrm{g}}$ & $182.50 \pm 1.14^{\mathrm{b}}$ & $131.75 \pm 1.59^{\mathrm{b}, \mathrm{e}}$ & $103.37 \pm 2.13^{\mathrm{b}}$ \\
\hline III. HLE.F ${ }_{1} 100 \mathrm{mg} / \mathrm{kg}$ b.w & $410.6 \pm 3.72^{\mathrm{c}}$ & $365.7 \pm 4.69^{c}$ & $370.3 \pm 6.13^{\mathrm{c}}$ & $314 \pm 16.68^{\mathrm{a}}$ & $326.8 \pm 7.74^{\mathrm{c}}$ \\
\hline IV. HLE.F ${ }_{1} 200 \mathrm{mg} / \mathrm{kg}$ b.w & $280.8 \pm 3.2^{\mathrm{a}}$ & $211.6 \pm 3.50^{\mathrm{b}}$ & $275.4 \pm 12.87^{\mathrm{a}}$ & $213.4 \pm 6.14^{\mathrm{c}}$ & $213.2 \pm 5.15^{\mathrm{d}}$ \\
\hline V. HLE. F $100 \mathrm{mg} / \mathrm{kg}$ b.w & $290.4 \pm 2.84^{\mathrm{a}}$ & $104.4 \pm 3.67^{\mathrm{d}}$ & $93.2 \pm 2.63^{\mathrm{d}}$ & $95.8 \pm 1.24^{\mathrm{d}}$ & $94.4 \pm 1.86^{\mathrm{e}, \mathrm{g}}$ \\
\hline VI. HLE. $F_{3} 200 \mathrm{mg} / \mathrm{kg}$ b.w & $278.6 \pm 4.89^{\mathrm{a}}$ & $126.1 \pm 4.29^{\mathrm{e}}$ & $161.4 \pm 3.59^{\mathrm{e}}$ & $120.6 \pm 3.08^{\mathrm{b}}$ & $90.2 \pm 25^{\mathrm{g}}$ \\
\hline VII. HLE.F $4100 \mathrm{mg} / \mathrm{kg}$ b.w & $258.22 \pm 3.77^{\mathrm{d}}$ & $184.67 \pm 4.75^{\mathrm{t}}$ & $170.14 \pm 6.51^{\mathrm{b}, \mathrm{e}}$ & $144.48 \pm 8.71^{\mathrm{e}}$ & $119.02 \pm 1.68^{\mathrm{t}}$ \\
\hline VIII. HLE.F $200 \mathrm{mg} / \mathrm{kg}$ b.w & $264.48 \pm 4.12^{\mathrm{d}}$ & $196.4 \pm 7.39^{\mathrm{f}, \mathrm{g}}$ & $143.54 \pm 4.51^{\mathrm{f}}$ & $122.94 \pm 3.27^{\mathrm{b}, \mathrm{e}}$ & $108.58 \pm 3.27^{\mathrm{b}, \mathrm{f}}$ \\
\hline IX. HLE. $\mathrm{F}_{5} 100$ mg/kg b.w & $280.8 \pm 3.57^{\mathrm{a}}$ & $204 \pm 5.74^{\mathrm{bg}}$ & $165.2 \pm 2.37^{\mathrm{e}}$ & $118.8 \pm 2.92^{\mathrm{b}}$ & $92.1 \pm 2.63^{\mathrm{e}, \mathrm{g}}$ \\
\hline X. HLE. F5 200 mg/kg b.w & $326.6 \pm 7.77^{\mathrm{e}}$ & $184.8 \pm 4.84^{\mathrm{t}}$ & $129.2 \pm 3.06^{\mathrm{t}}$ & $113 \pm 3.4^{\mathrm{b}, \mathrm{d}}$ & $83.8 \pm 3.15^{\mathrm{g}}$ \\
\hline ANOVAF Value $(\mathrm{df}=9,40)$ & 130.705 & 240.725 & 221.762 & 115.651 & 553.615 \\
\hline
\end{tabular}

Values are mean \pm SE from 5 animals in each group. All values are significant at $\mathrm{P}<0.05$ vs diabetic control (Gr.1)

Table 2. Effect of leaf extract of $\mathrm{H}$. rosa sinensis (HLE) fractions $\left(\mathrm{F}_{3}, \mathrm{~F}_{4}, \mathrm{~F}_{5}\right)$ treatment on pancreas, Islet size and $\beta$ - cell number.

\begin{tabular}{|c|c|c|c|c|}
\hline Groups & Weight of pancreas & $\begin{array}{c}\text { Relativeweight of } \\
\text { Pancreas }\end{array}$ & $\begin{array}{l}\text { Diameter of iset } \\
\text { in } \mu \mathrm{m}\end{array}$ & Number of $\beta$ cell/islet \\
\hline I. NOD diabetic control & $0.185 \pm 0.004^{\mathrm{a}}$ & $0.682 \pm 0.011^{\mathrm{a}, \mathrm{b}}$ & $121.52 \pm 2.43^{\mathrm{a}}$ & $93.1 \pm 2.69^{\mathrm{a}}$ \\
\hline II. In sulin injected NOD Mice & $0.194 \pm 0.009^{\mathrm{a}}$ & $0.611 \pm 0.028^{\mathrm{a}}$ & $154.02 \pm 3.32^{\mathrm{b}}$ & $143.36 \pm 1.57^{\mathrm{b}}$ \\
\hline III. HLE.F F $_{3}-100$ mg/kg/b.w & $0.201 \pm 0.001^{\mathrm{a}, \mathrm{b}, \mathrm{c}}$ & $0.625 \pm 0.006^{\mathrm{a}}$ & $145.66 \pm 2.19^{\mathrm{c}, \mathrm{e}}$ & $170.37 \pm 1.47^{\mathrm{c}}$ \\
\hline IV. HLE.F3. $200 \mathrm{mg} / \mathrm{kg}$ b.w & $0.206 \pm 0.009^{\mathrm{a}, \mathrm{b}, \mathrm{c}}$ & $0.635 \pm 0.029^{\mathrm{a}}$ & $140.04 \pm 2.67^{\mathrm{c,d}}$ & $146.4 \pm 7.48^{\mathrm{b}}$ \\
\hline V. HLE.F $4^{-} 100 \mathrm{mg} / \mathrm{kg} / \mathrm{b} . \mathrm{w}$ & $0.224 \pm 0.009^{\mathrm{b}}$ & $0.724 \pm 0.029^{\mathrm{b}}$ & $137.6 \pm 1.87^{\mathrm{d}}$ & $129.24 \pm 2.90^{\mathrm{d}}$ \\
\hline VI. HLE.F ${ }_{4}-200 \mathrm{mg} / \mathrm{kg} / \mathrm{b} . \mathrm{w}$ & $0.197 \pm 0.003^{\mathrm{acc}}$ & $0.635 \pm 0.014^{\mathrm{a}}$ & $138.8 \pm 1.69^{\mathrm{d}}$ & $130.2 \pm 0.54^{\mathrm{d}}$ \\
\hline VII. HLE.F $F_{5}-100 \mathrm{mg} / \mathrm{kg} / \mathrm{b} . \mathrm{w}$ & $0.206 \pm 0.003^{\mathrm{a}, \mathrm{b}, \mathrm{c}}$ & $0.640 \pm 0.008^{\mathrm{a}}$ & $149.2 \pm 0.98^{\mathrm{b}, \mathrm{e}}$ & $138.2 \pm 1.42^{\mathrm{b}, \mathrm{d}}$ \\
\hline VIII. HLE.F5-200 mg/kg/b.w & $0.218 \pm 0.010^{\mathrm{b}, \mathrm{c}}$ & $0.68 \pm 0.038^{\mathrm{ab}}$ & $150.4 \pm 1.49^{\mathrm{b}, \mathrm{e}}$ & $143.4 \pm 2.01^{\mathrm{b}}$ \\
\hline ANOVA F Value $(\mathrm{df}=7,32)$ & 3.113 & 2.583 & 21.746 & 45.972 \\
\hline
\end{tabular}

The values are given as means $\pm \mathrm{SE}$; df, degrees of freedom in each group. Means with different superscripts $(\mathrm{a}, \mathrm{b}$ and $\mathrm{c})$ within $\mathrm{a}$ column are significantly different from each other at $\mathrm{p}<0.05$ as determined by Duncan's multiple range test.

glucose level to non diabetic status. Treatment of $\mathrm{H}$.rosa sinensis leaf extract in different fractions $\left(\mathrm{F}_{3}, \mathrm{~F}_{4}, \mathrm{~F}_{5}\right)$ to the NOD mice had significantly increased the islet size and $\beta$-cell number when compared to the diabetic group (group-I). The diminished islet size and $\beta$-cells numbers resulted in the histopathology of diabetic pancreas. Reduction of $\beta$-cells number and islet diameter indicates the loss of integrity between the cells in the islet. Decreased activity of the antioxidant enzymes and depletion of total antioxidant capacity may increase the susceptibility of diabetic patients to oxidative injury. The recent report shows that the number of adult $\beta$-cells can increase through self duplication/proliferation (Dor et al., 2004) supports present study that increase in the islet size and $\beta$-cells number in the diabetic islets can happen after treatment with $\mathrm{H}$. rosa sinensis leaf extract in different fractions $\left(\mathrm{F}_{3}, \mathrm{~F}_{4}, \mathrm{~F}_{5}\right)$. Because of oral treatment of different fractions $\left(\mathrm{F}_{3}, \mathrm{~F}_{4}, \mathrm{~F}_{5}\right)$ to NOD mice there was not only enhancement of diameter of islets and increase in the number of $\beta$-cells in the islet but also in the secretion of insulin (Moqbel et al., 2011) for fractions $\mathrm{F}_{3}$ and $\mathrm{F}_{5} . \mathrm{F}_{4}$ also enhanced insulin secretion (unpublished data) compared to NOD mice. Thus these fractions may contain the active component/s that enhance insulin secretion in NOD mice by one or several the mechanisms. Enhancement of insulin secretion in NOD mice may be through antioxidant supplies which may help to prevent clinical complications of diabetes mellitus (RahbaniNobar et al., 1999). However, relationships between the antioxidant status, glycemic control and the risk for development of chronic complications in individuals with diabetes are not completely understood (Abuaisha et al., 1998).

\section{REFERENCES}

Abuaisha, B., Kumar, S. and Malik, R. (1998). Relationship of elevated urinary albumin excretion to components of the metabolic syndrome in non-insulin-dependent diabetes mellitus. Diabetes Res clin pract., 39: 93-99.

Acha-Orbea, H. and McDevitt, H. O. (1990). The role of class II molecules in development of insulin-dependent diabetes 
mellitus in mice, rats and humans. Curr. Top. Microbiol. Immunol., 156: 103-119.

Alberti, K.G.M.M., Zimmet, P. and DeFronzo, R.A. (1997). International Textbook Diabetes Mellitus, 2nd ed. John Wiley and Sons, New York.

Berker, K. I., Guclu, K., Top, I., Demirata, B. and Apak, R. (2009). Total antioxidant capacity Assay Using Optimized Ferricyanide/Prussian Blue Method. Food Anal. M ethods. DOI 10. 1007/s 12161-9117-9.

Cahill, GF. and McDevitt, H.O. (1981). Insulin-dependent diabetes mellitus: the initial lesion. N. Engl. J. M ed., 304 : 1454-1465.

Castano, L. and Eisenbarth, G. S. (1990). Type-I diabetes: a chronic autoimmune disease of human, mouse, and rat. Annu. Rev. Immunol., 8: 647-679.

Chandavar, V. R. and Naik, P. R. (2004).Variation in plasma glucose and pancreatic $\beta$-cell in the turtle Lissemys punctata (order: Chelonia; Family: Trionycnidae). Acta Zoologica (Stockholm), 85: 113-118.

Dor, Y., Brown, J., Martinez, Ol. and Melton, DA. (2004). Adult pancreatic $\beta$-cells are formed by self-duplication rather than stem cell differentiation. Nature, 429: 41-46.

Ganong, W. (1999). Review of medical physiology. Stamford, Connecticut, Appleton and Lange, 324-328.

Gauthaman, K. K., Saleem, M. T., Thanislas, P. T., Prabhu, V. V., Krishnamoorthy, K. K., Devaraj, N. S. and Somasundaram, J. S. (2006). Cardioprotective effect of the $\mathrm{Hibiscus}$ rosa-sinensis flowers in an oxidative stress model of myocardial ischemic reperfusion injury in rat. BMC Complementary and Alternative M edicine, 6:32.

Gorsuch, A. N., Spencer, K. M., Lister, J., McNally, J.M., Dean, B.M., Tottazzo, G. F. and Cudworth, A. G. (1981). Evidence for a long prediabetic period in type 1 insulindependent) diabetes mellitus. Lancet, 2:1363-1365,

Makino, S., Kunimoto, K., Muraoka, Y., Mizushima, Y., Katagiri, K. and Tochino, Y. (1980). Breeding of a nonobese diabetic strain of mice. J ikken D obutsu., 29: 1-13.

Masaki, H. S., Sakaki, S., Atsumi, T. and Sakurai, H. (1995). Active oxygen scavenging activity of plant extracts. Biol. Pharmacol. Bull., 18: 162-166.

Moqbel, F.S., Naik, P.R., Najma, H.M. and Selvaraj, S. (2011). Antidiabetic properties of Hibiscus rosa sinensis L. leaf extract fraction on non-obese diabetic (NOD) mouse. Ind. J . Exp. Biol., 49: 24-29.

Nazirog;lu, M. and Butterworth, P. (2005). Protective effects of moderate exercise with dietary vitamin $\mathrm{C}$ and $\mathrm{E}$ on blood antioxidative defense mechanism in rats with streptozotocin induced diabetes. CanJ A ppl Physiol., $30: 172-185$.

Obi, F. O. and Uneh, E, PH. (2003). dependant prevention of carbontetrachloride-induce lipoperoxidation in rats by ethanolic extract of $\mathrm{Hibiscus}$ rosa-sinensis petals. Biokemistri, $13: 42-50$.

Packer, L., Rfsen, P., Tritschler, H.J., King, G.L. and Azzi, A. (2000). Antioxidants diabetes management. Marcel Dekker, New York, pp. 1-338.

Philippe, J. (1991). Structure and pancreatic expression of the insulin and glucagon genes. Endocrine Reviews. $12: 252$ 271.

Polidori, M.C., Mecocci, P., Stahl, W, Parente, B., Cecchetti, R., Cherubini, A., Cao P., Sies, H. and Senin, U. (2000). Plasma levels of lipophilic antioxidants in very old patients with type II diabetes. Diabetes M etab Res Rev, 16:15-19.

Rahbani-Nobar, M. E., Rahimi-pour, A., Rahbani-Nobar, M., Adi-Beig and Mirhashemi, S. M. (1999). Total antioxidant capacity, superoxide dismutase and glutathion peroxidase in diabetic patients. M edical J ournal of I slamic Academy of Sciences, 12: 109-114.

Rossini, A., Mordes, J. P. and Greiner, D. L. (1989). The pathogenesis of autoimmune diabetes mellitus. Curr. O pinion Immunol., 2: 598-603.

Sachdewa, A. and Khemani, L. D. (2003). Effect of H ibiscus rosa-sinensis Linn. ethanol flower extract on blood glucose and lipid profile in streptozotocin induced diabetes in rats. J ournal of E thnopharmacology, 89: 61-66.

Sharma, S., Khan, N. and Sultana, S. (2004). Study on prevention of twostage skin carcinogenesis by Hibiscus rosa sinensis extract and the role of its chemical constituent, gentisic acid, in the inhibition of tumor promotion response and oxidative stress in mice. Euro I Cancer Prevent, 13: 53-63.

Shinn, S.H. (1998). Oxidative stress and diabetic vascular complications. In: Recent advances on pathogenesis and management of diabetes mellitus. 1st ed, Elsevier Science Co, Singapore, pp 3-8. 